\title{
Layanan e-Surat Berbasis Mobile Application di Desa Waru Barat Pamekasan
}

\author{
Badar Said, Fauzan Prasetyo E.P. \\ Prodi Informatika Fakultas Teknik Universitas Madura, Jl. Raya Panglegur KM 3,5 Pamekasan, Jawa Timur, Indonesia
}

\begin{tabular}{l} 
KEYWORDS \\
\hline e-surat, pelayanan, desa, mobile \\
CORRESPONDENCE \\
\hline Phone: - \\
E-mail: badarsaid@unira.ac.id,
\end{tabular}

\section{PENDAHULUAN}

Pemerintahan Desa merupakan penyelenggaraan urusan pemerintahan dan kepentingan masyarakat setempat dalam sistem pemerintahan Negara Kesatuan Republik Indonesia[1]. Dalam pelaksanaan pelayanan publik di tingkat pemerintahan desa sampai saat ini masih banyak yang belum memanfaatkan teknologi secara maksimal. Salah satunya untuk pembuatan surat yang dibutuhkan oleh warga desa. Hal ini juga terjadi di Desa Waru Barat Kecamatan Waru Kabupaten Pamekasan.

Waru Barat merupakan Desa yang terletak di pusat administrasi kecamatan yaitu kecamatan Waru kabupaten Pamekasan. Letak Desa yang sangat strategis di kawasan utara pulau Madura membuat Waru Barat menjadi salah satu primadona parameter pembangunan perekonomian baik mikro ataupun makro. Secara Demografi, Waru Barat memiliki 11 Dusun dengan total penduduk mencapai 16645 jiwa.

Degan banyaknya jumlah penduduk serta masih belum maksimalnya pemanfaatan teknologi mengakibatkan pelayanan publik sangat terganggu. Sering kali warga harus menunggu satu sampai dua hari untuk proses pembuatan surat. Hal itu disebabkan oleh beberapa persoalan, diantaranya keterbatasan perangkat, lemahnya keahlian sumber daya manusia, serta ketersediaan data yang kurang akurat untuk proses pembuatan surat tersebut. Pemanfaatan teknologi di Desa Waru Barat hanya sebatas penggunaan aplikasi perkantoran dasar, sedangkang disisi lain mayoritas warga sudah menggunakan teknologi gadget terutama para kaum muda, dengan berbagai aplikasi mobile seperti aplikasi social media dan lain sebagainya

Dari fakta diatas maka sangat layak apabila dilakukan penerapan e-surat berbasis mobile di Desa Waru Barat. Setiap warga akan sangat mudah melakukan permohonan pembuatan surat dari mana saja dan kapan saja melalui gadget masing-masing. Warga hanya memilih jenis surat dan mengisi NIK dan beberapa keterangan tentang surat yang akan dibuat. Data lain seperti nama, jenis kelamin, pekerjaan secara otomatis muncul apabila NIK sesuai dengan data pada aplikasi. Aparatur desa juga akan dimudahkan karena hanya cukup melakukan validasi dan mencetak surat yang telah diisi oleh warga secara online. 
Sehingga tujuan pemerintah untuk meningkatkan pengelolaan dan pelayanan informasi di lingkungan Badan Publik untuk menghasilkan layanan informasi yang berkualitas dapat terwujud[2].

\section{TINJAUAN PUSTAKA}

Dalam melakukan penelitian ini terdapat beberapa referensi yang digunakan antara lain sebagai berikut:

\section{Layanan Surat-menyurat di Desa}

Surat menyurat adalah salah satu jenis pelayanan paling penting yang ada di setiap Desa. Berhubungan dengan aspek pelayanan kepada masyarakat atau warga desa, Pusat Kajian Otonomi Daerah telah melakukan kajian yang hasilnya menyetakan perlu secara terusmenerus dilakukan peningkatan kualitas pelayanan pemerintah desa, baik pelayanan yang sifatnya internal maupun eksternal, baik berupa fisik maupun administrative[3]. Dari hasil wawancara terdapat beberapa layanan surat-menyurat yang sediakan oleh desa Waru barat yaitu:

1. Surat keterangan tidak mampu

2. Surat keterangan domisili perorangan dan instansi

3. Surat keterangan usaha

4. Surat keterangan kehilangan

5. Surat keterangan beda identitas

6. Surat keterangan berkelakukan baik

7. Surat keterangan bekerja diluar daerah

8. Surat keterangan kelahiran

9. Surat keterangan kematian

10. Surat keterangan pindah dan pindah datang

11. Surat permohonan SKCK

12. Surat permohonan izin terlambat

13. Surat permohonan izin keramaian

14. Surat permohonan KTP

15. Surat keterangan untuk nikah

16. Surat keterangan asal-usul

17. Surat persetujuan mempelai

18. Surat keterangan orang tua

\section{Prototyping}

Prototyping adalah salah satu metode pengembangan perangat lunak, yang berbentuk model fisik kerja sistem dan berguna sebagai versi awal dari sebuah sistem. Dengan metode ini akan dihasilkan prototype sistem yang beguna sebagai perantara pengembang dengan pengguna agar dapat berinteraksi dalam proses pengembangan sistem informasi. proses pembuatan prototype ini akan berhasil dengan baik apabila dilakukan pendefinisian aturan-aturan pada tahap awal, sehingga pengembang dan penguna harus memiliki pemahaman yang sama. prototype dibangun untuk mendefinisikan kebutuhan awal, dan akan dihilangkan atau ditambahkan pada bagiannya sehingga sesuai dengan rencana dan analisis sampai dengan ujicoba. Semuanya dilakukan secara simultan sesuai dengan proses pengembangan[4].

Metode prototyping ini sangat baik apabila digunakan ketika pengguna atau client tidak dapat memberikan gambaran secara rinci mengenai kebutuhan yang diharapkan, sehingga pengembang aplikasi sulit untuk menentukan input, proses, maupun output yang lebih rinci, Adapun flowchart Prototyping dapat dilihat pada gambar berikut ini[5].

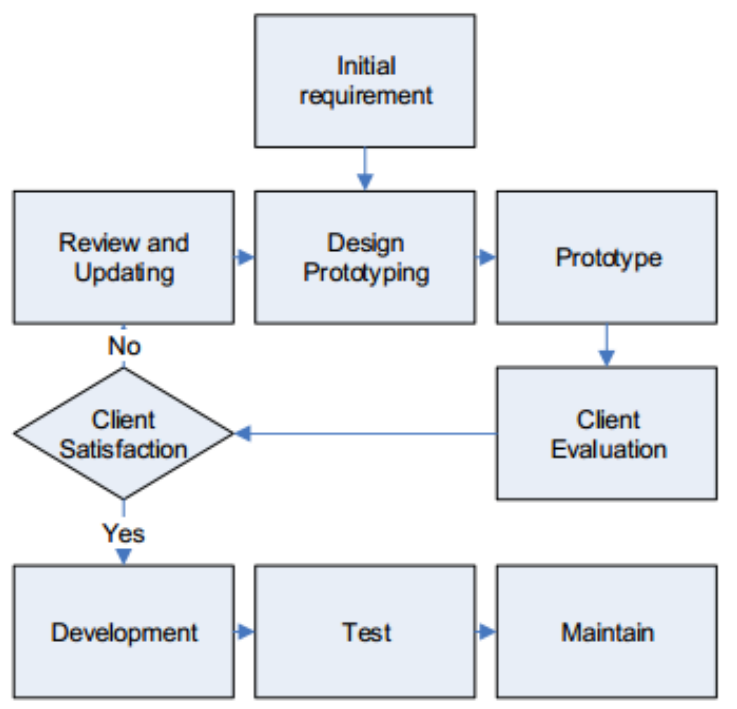

Gambar 1. Flowchart Prototyping

\section{Slim Framework}

Slim Framework adalah mikro framework sederhana yang menggunakan bahasa pemrograman PHP dalam membangannya, sering digunakan untuk membangun webservice atau juga sering disebut REST API. Slim Framework memiliki konsep kerja yang sangat sederhana. Slim Framework bertugas menerima HTTP Request, setelah itu memanggil fungsi yang diinginkan. Kemudian mengirimkan HTTP Response. Slim framework sering digunakan sebagai backend dalam pengembangan sebuah aplikasi[5]

\section{Angular 6}

Angular adalah framework javascript dengan konsep ModuleView-Controler (MVC) dan bersifat open source. Angular sering digunakan untuk frontend dalam mengembangkan aplikasi web. Angular dikembangkan oleh Google sehingga banyak digunakan oleh frontend developer. Angular menggunakan Bahasa pengembangan dari bahasa Javascript yaitu Typescript yang merupakan bahasa utama yang digunakan untuk pengembangan website[5].

\section{Ionic 3}

Ionic adalah salah satu framework yang digunakan untuk membangun aplikasi mobile hybrid dengan HTML5, CSS dan angular. Ionic menggunakan teknologi web, sehingga ionic berjalan diatas layer web. Framework ini menggunakan HTML5 dan CSS sebagai User Interface Component dan angular digunakan sebagai route. Kelebihan framework ini antara lain dapat membuat aplikasi mobile lintas platform Hanya dengan satu kali koding[5].

\section{System Usability Scale (SUS)}

System Usability Scale dikembangkan oleh John Brooke, SUS merupakan alat untuk membuat skala yang andal, populer, efektif, dan murah, yang berguna untuk memberikan penilaian global terhadap kegunaan sebuah sistem. SUS menggunakan sepuluh komponen pertanyaan dengan lima pilihan jawaban, mulai dari sangat setuju sampai sangat tidak setuju, serta memiliki skor 
minimal 0 dan maksimal 100. SUS yang sudah diterjemahkan ke dalam bahasa Indonesia seperti ditunjukkan pada Tabel 1 [6].

Tabel 1. Komponen pertanyaan SUS

\begin{tabular}{cl}
\hline No & Komponen Pertanyaan \\
\hline 1 & Saya berpikir akan menggunakan sistem ini lagi. \\
\hline 2 & Saya merasa sistem ini rumit untuk digunakan. \\
\hline 3 & Saya merasa sistem ini mudah digunakan. \\
\hline 4 & $\begin{array}{l}\text { Saya membutuhkan bantuan dari orang lain atau } \\
\text { teknisi dalam menggunakan sistem ini. }\end{array}$ \\
\hline 5 & $\begin{array}{l}\text { Saya merasa fitur-fitur sistem ini berjalan dengan } \\
\text { semestinya. }\end{array}$ \\
\hline 6 & $\begin{array}{l}\text { Saya merasa ada banyak hal yang tidak konsisten } \\
\text { tidak serasi pada sistem ini). }\end{array}$ \\
\hline 7 & $\begin{array}{l}\text { Saya merasa orang lain akan memahami cara } \\
\text { menggunakan sistem ini dengan cepat. }\end{array}$ \\
\hline 8 & Saya merasa sistem ini membingungkan. \\
\hline 9 & $\begin{array}{l}\text { Saya merasa tidak ada hambatan dalam menggunakan } \\
\text { sistem ini. }\end{array}$ \\
\hline 10 & $\begin{array}{l}\text { Saya perlu membiasakan diri terlebih dahulu sebelum } \\
\text { menggunakan sistem ini. }\end{array}$ \\
\hline
\end{tabular}

Skor SUS di atas 68 dianggap di atas rata-rata, karena Skor ratarata SUS dari banyak penelitian adalah 68. Namun pada penelitian terdahulu, sudah ditetapkan dasar penilaian yang tepat, seperti ditunjukkan pada Gambar 2 [6].

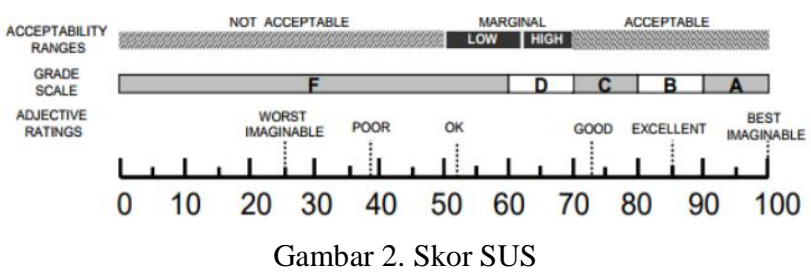

\section{METODOLOGI}

Metodologi dalam penelitian ini dibagi menjadi dua bagian yaitu pengembangan sistem dan pengujian usability:

\section{Pengembangan Sistem}

Pengembangan aplikasi e-surat ini menggunakan metode prototyping dengan tahapan sebagai berikut:

1. Initial Requirement

Pada tahapan ini pengumpulan data dilakukan dengan observasi, wawancara, dan studi dokumen. Data yang dikumpulkan meliputi pengguna yang akan terlibat didalam pembuatan surat-menyurat, data jenis surat, serta format cetak dari masing-masing jenis surat. Konsep aplikasi yang diharapkan juga dibahas untuk memperjelas teknologiteknologi yang akan diterapkan. Hal ini dilakukan untuk mempermudah dalam proses perancangan.

2. Design Prototyping

Tahapan ini merupakan perancangan berdasarkan hasil pengumpulan data pada tahapan sebelumnya. Perancangan yang dilakukan dimulai dari konsep umum aplikasi, perancangan database, sampai perancangan interface aplikasi yang diwujudkan dalam bentuk prototype. Dalam tahapan ini dapat dilakukan perbaikan-perbaikan terhadap prototype yang telah dibuat berdasarkan hasil evaluasi dari pengguna atau client. Gambaran umum aplikasi e-surat ditunjukkan pada gambar 3 .

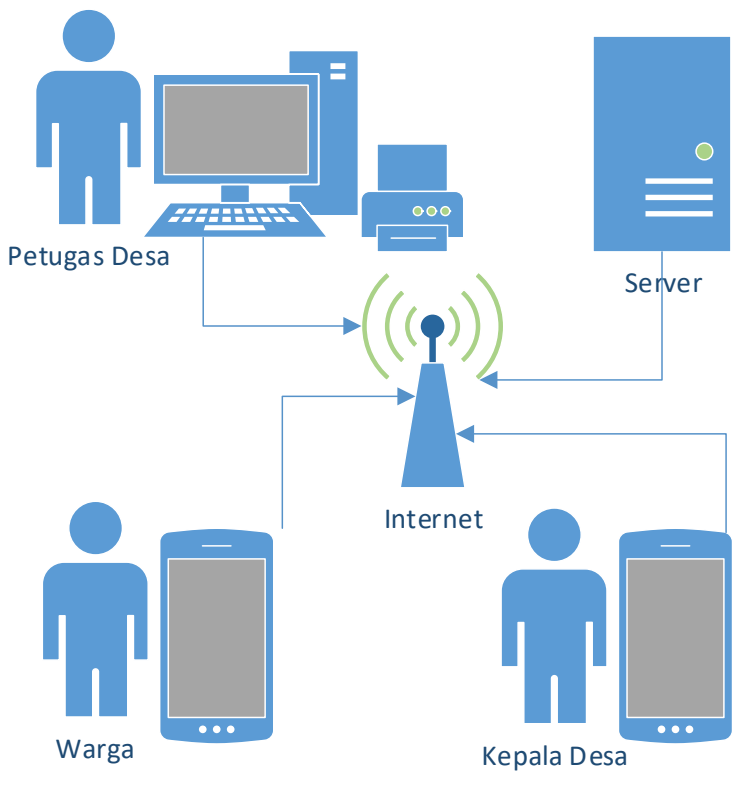

Gambar 3. Gambaran umum aplikasi e-surat

Pada gambar diatas dapat diperjelas bahwa warga dapat mengajukan permohonan surat menggunakan smartphone dengan hanya mengetikan NIK dan jenis surat. Pengajuan yang telah dikirim akan muncul pada smartphone Kepala Desa untuk disetujui. Pengajuan surat yang telah disetujui langsung bisa dicetak oleh petugas desa dan memberikan informasi kepada pemohon bahwa surat sudah bisa diambil ke kantor desa. Semua data tersimpan didalam komputer server dan dapat diakses melalui koneksi internet.

3. Client Evaluation

Sebelum dilakukan langkah selanjutnya, pengguna harus melakukan evaluasi terhadap prototype hasil perancangan, sehingga dapat diketahui prototype yang telah dibuat sudah sesuai atau tidak.

4. Development

Tahapan ini dilakukan menggunakan slim framework, Angular 6, dan Ionic 3. Proses coding dilakakukan apabila prototype yang telah dibuat sudah selesai dievaluasi dan sudah sesuai dengan kebutuhan pengguna.

5. Test

Pengujian dilakukan secara bertahap terhadap hasil coding sampai sesuai dengan prototype yang telah divalidasi.

6. Maintain

Setelah ujicoba dilakukan secara keseluruhan, maka perlu dilakukan proses maintain untuk memastikan semua fitur dapat digunakan secara baik pada saat aplikasi sudah digunakan.

\section{Pengujian Usability}

Setelah pengembangan sistem selesai dilakukan, selanjutnya dilakukan pengujian usability untuk mengetahui penilaian pengguna terhadap aplikasi yang telah dibuat. Penilaian dilakukan oleh 20 responden yaitu 15 responden dari warga dan 5 responden dari aparatur desa. penentuan jumlah responden sebanyak 20 sudah cukup berdasarkan penelitian terdahulu[6]. Sebelumnya responden diminta untuk menggunakan aplikasi e- 
surat berdasarkan hak aksesnya masing-masing, kemudian melakukan penilai menggunakan System Usability Score (SUS) dalam bentuk kuesioner yang telah disediakan.

Berikut ini aturan-aturan saat perhitungan skor pada kuesioner SUS[6]:

1. Setiap pertanyaan bernomor ganjil, skor setiap pertanyaan yang didapat dari skor pengguna dikurangi 1.

2. Setiap pertanyaan bernomor genap, skor akhir didapat dari nilai 5 dikurangi skor pertanyaan yang didapat dari pengguna.

3. Skor SUS didapat dari hasil penjumlahan skor setiap pertanyaan yang kemudian dikali 2,5.

\section{HASIL DAN PEMBAHASAN}

Pembahasan hasil pengembangan sistem dan pengujian usability dalam penelitian ini dipaparkan sebagai berikut:

\section{Hasil Pengembangan Sistem}

Setelah dilakukan pengembangan sistem menggunakan metode prototyping, dihasilkan aplikasi e-surat berbasis mobile application sebagai berikut.

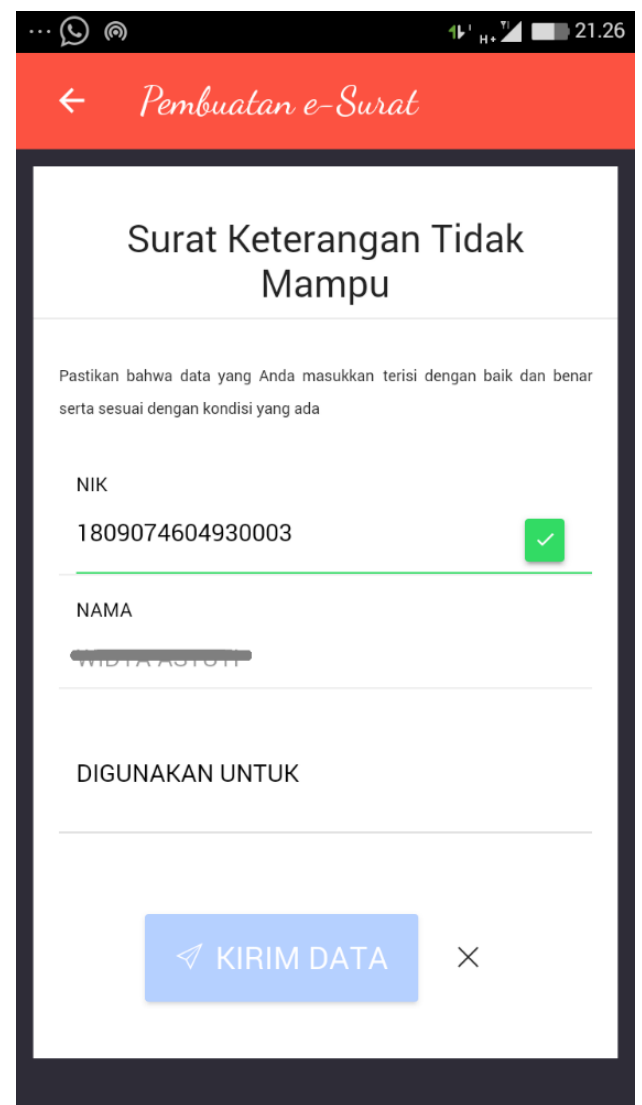

Gambar 4. Halaman pengajuan surat

Pada gambar diatas ditunjukkan bahwa warga dapat mengajukan permohonan surat menggunakan smartphone, warga hanya memilih jenis surat, kemundian mengisi NIS dan data keterangan yang lain. Data pribadi pemohon otomatis muncul karena sebelumnya sudah dilakukan proses data import dalam bentuk file .csv kedalam database yang berasal dari data DISPENDUKCAPIL Pamekasan. Data pengajuan surat yang telah dikirim dapat divalidasi oleh kepala desa dan petugas desa, seperti ditunjukkan pada gambar 5 .

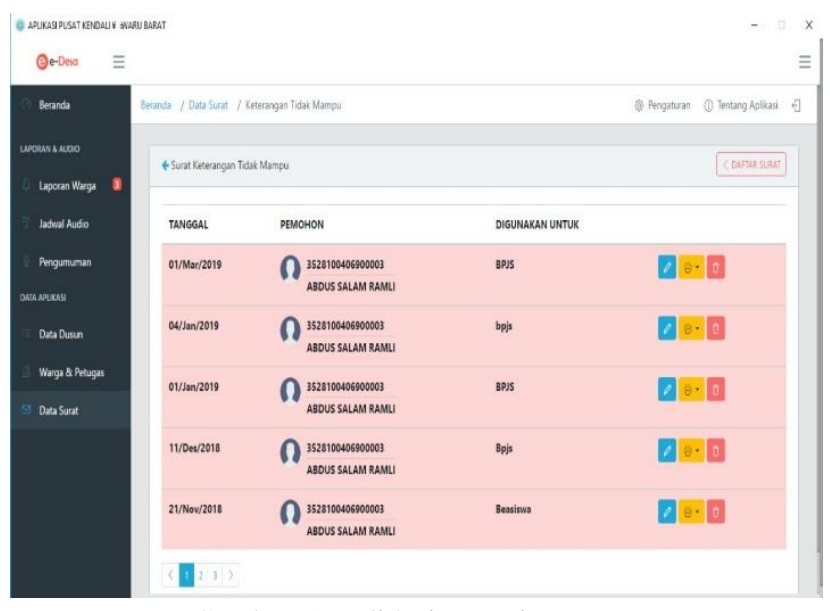

Gambar 5. Validasi pengajuan surat

Setelah proses validasi maka surat sudah dapat dicetak dan sistem otomatis memberikan informasi kepada pemohon bahwa surat yang diajukan sudah bisa diambil ke kantor desa.

Selain proses pengajuan, validasi, dan cetak surat, petugas desa maupun kepala desa dapat mengetahui rekap pengajuan untuk masing-masing layanan surat-menyurat setiap saat, sehingga dapat digunakan sebagai bahan evaluasi dan proyeksi terkait program pelayanan surat-menyurat selanjutnya.

\section{Hasil Pengujian Usability}

Pengujian usability dilakukan menggunakan kuesioner SUS terhadap 20 responden. Data yang diperoleh dari kuesioner SUS kemudian dilakukan perhitungan sesuai dengan aturan dalam analisis data SUS. Data hasil perhitungan SUS ditunjukkan pada tabel berikut:

Tabel 2. Hasil Perhitungan SUS

\begin{tabular}{|c|c|c|c|c|c|c|c|c|c|c|c|c|c|}
\hline \multirow{2}{*}{ No } & \multirow{2}{*}{ Reponden - } & \multicolumn{10}{|c|}{ Skor Hasil Perhitungan SUS } & \multirow{2}{*}{ Jumlah } & \multirow{2}{*}{ Nilai } \\
\hline & & Q1 & Q2 & Q3 & Q4 & Q5 & Q6 & Q7 & Q8 & Q9 & Q10 & & \\
\hline 1 & R1 & 4 & 4 & 4 & 4 & 4 & 3 & 4 & 4 & 3 & 4 & 38 & 95 \\
\hline 2 & R2 & 4 & 2 & 4 & 2 & 4 & 2 & 4 & 2 & 2 & 4 & 30 & 75 \\
\hline 3 & $\mathrm{R} 3$ & 3 & 3 & 3 & 3 & 2 & 3 & 2 & 4 & 3 & 4 & 30 & 75 \\
\hline 4 & R4 & 4 & 2 & 4 & 2 & 4 & 3 & 4 & 2 & 4 & 2 & 31 & 78 \\
\hline 5 & R5 & 3 & 3 & 3 & 3 & 3 & 3 & 3 & 3 & 3 & 3 & 30 & 75 \\
\hline 6 & R6 & 3 & 3 & 3 & 3 & 4 & 4 & 4 & 3 & 4 & 3 & 34 & 85 \\
\hline 7 & R7 & 3 & 3 & 3 & 3 & 3 & 3 & 3 & 3 & 2 & 3 & 29 & 73 \\
\hline 8 & $\mathrm{R} 8$ & 4 & 3 & 4 & 3 & 4 & 2 & 4 & 3 & 2 & 3 & 32 & 80 \\
\hline 9 & R9 & 3 & 3 & 3 & 4 & 4 & 2 & 4 & 4 & 3 & 3 & 33 & 83 \\
\hline 10 & R10 & 3 & 3 & 3 & 3 & 3 & 2 & 3 & 3 & 3 & 3 & 29 & 73 \\
\hline 11 & R11 & 3 & 3 & 3 & 3 & 3 & 2 & 3 & 3 & 3 & 3 & 29 & 73 \\
\hline 12 & R12 & 3 & 3 & 3 & 3 & 3 & 2 & 3 & 3 & 3 & 3 & 29 & 73 \\
\hline 13 & R13 & 4 & 4 & 4 & 4 & 4 & 4 & 4 & 4 & 3 & 4 & 39 & 98 \\
\hline 14 & R14 & 3 & 3 & 3 & 3 & 4 & 3 & 4 & 3 & 3 & 3 & 32 & 80 \\
\hline 15 & R15 & 3 & 3 & 3 & 3 & 3 & 3 & 3 & 3 & 3 & 3 & 30 & 75 \\
\hline 16 & R16 & 4 & 4 & 4 & 4 & 3 & 4 & 3 & 4 & 3 & 4 & 37 & 93 \\
\hline 17 & R17 & 3 & 3 & 3 & 3 & 4 & 3 & 4 & 3 & 3 & 3 & 32 & 80 \\
\hline 18 & R18 & 4 & 3 & 4 & 3 & 4 & 4 & 4 & 3 & 3 & 3 & 35 & 88 \\
\hline 19 & R19 & 4 & 4 & 4 & 4 & 3 & 4 & 3 & 4 & 3 & 3 & 36 & 90 \\
\hline 20 & R20 & 4 & 3 & 4 & 3 & 3 & 3 & 3 & 3 & 3 & 3 & 32 & 80 \\
\hline & & & & & or & a & & & & & & & 81 \\
\hline
\end{tabular}

Dari data hasil perhitungan SUS diatas, diperoleh skor rata-rata 81. Skor ini tergolong skor diatas rata-rata apabila dibandingkan dengan skor rata-rata SUS dari banyak penelitian yaitu 68[6]. 


\section{KESIMPULAN}

Skor SUS yang sudah didapatkan yaitu 81 apabila diproyeksikan pada ketentuan penilaian SUS pada gambar 2 menunjukkan Acceptability range $=$ Acceptable, Grade scale $=$ B, dan Adjective rating=Excellent. Sehingga dapat disimpulkan bahwa penerapan aplikasi e-surat di Desa Waru Pamekasan dinilai sangat baik.

Selanjutnya dapat dilakukan pengembangan untuk fitur validasi dari kepala desa menggunakan tanda tangan digital (Digital Signature).

\section{UCAPAN TERIMA KASIH}

Terima kasih kami ucapkan kepada Universitas Madura yang telah mendanai penelitian ini pada tahun anggaran 2018.

\section{DAFTAR PUSTAKA}

[1] Indonesia. Presiden Republik Indonesia, Undang-Undang Republik Indonesia Nomor 6 Tahun 2014 Tentang Desa. Indonesia: Kementerian Hukum dan Hak Asasi Manusia Republik Indonesia; 2014.

[2] Indonesia. Presiden Republik Indonesia, Undang-Undang Republik Indonesia Nomor 14 Tahun 2008 Tentang Keterbukaan Informasi Publik. Indonesia: Kementerian Hukum dan Hak Asasi Manusia Republik Indonesia; 2008.

[3] Y. Sibaroni, M. Imrona, E. B. Setiawan, dan F. A. Dzuhri, "Aplikasi Pelayanan Administrasi Penduduk Desa Berbasis Web Programing" Seminar Nasional Aplikasi Teknologi Informasi (SNATi), Yogyakarta, pp. 1-6, Juni 2015.

[4] D. Purnomo, "Model Prototyping Pada Pengembangan Sistem Informasi" JIMP-Jurnal Informatika Merdeka Pasuruan, Vol.2 No.2, pp. 54-61, Agustus 2017.

[5] A. W. Syahroni dan Ubaidi, "Implementasi Darurat Keamanan Dan Kesehatan Berbasis Mobile Di Desa Waru Barat Pamekasan" InfoTekJar : Jurnal Nasional Informatika Dan Teknologi Jaringan, vol. 3 no. 2, pp. 71-75, Maret 2019.

[6] E. Susilo, F. D. Wijaya, dan R. Hartanto, "Perancangan dan Evaluasi User Interface Aplikasi Smart Grid Berbasis Mobile Application" JNTETI, Vol. 7, No. 2, , pp. 150-157, Mei 2018.

[7] Ubaidi, "Sistem Informasi Presensi Realtime dengan Menggunakan Fingerprint dan SMS Gateway di Pondok Pesantren Al-Amien Prenduan Madura" Jurnal SPIRIT Vol. 10 No. 2, pp. 66-71, Nopember 2018.

[8] S. Rachmatullah dan I. Gunawan, "Aplikasi Tracer Study Universitas Madura" Jurnal Insand Comtech, Vol. 1, No. 2, pp. 31-37, September 2016.

[9] F. Prasetyo dan U. Fajri, "Aplikasi Manajemen Proyek dengan Metode Critical Path Method (CPM) pada Dekstop dan Android" SEMNASKIT Politeknik Negeri Jember, pp. 180-183, Desember 2015.

[10] N. H. Hari, F. Prasetyo, Hamdlani, “Optimasi Penjadwalan Menggunakan Metode Algoritma Genetika di Sekolah Menengah Kejuruan Annuqayah - Sumenep" QUERY: Jurnal Sistem Informasi Volume: 02, Number: 02, pp. 6674, Oktober 2018. 